\title{
Conversational Implicature Instruction as a Pedagogical Strategy for English Majors in a Chinese Context: A Pragmatic-Analysis of Its Effectiveness
}

\author{
Shifang Li \\ School of Languages and Cultures, Shanghai University of Political Science and Law, China
}

\begin{abstract}
In English teaching, teachers have always attached great importance to exploring scientific listening teaching methods to improve students' listening comprehension ability. In order to improve the listening teaching mode, scholars in both China and in other countries have done a series of studies. However, there is little research on the effectiveness of conversational implicature in improving listening comprehension ability of English majors. Therefore, through empirical research, this paper explores the effectiveness of applying the Conversational Implicature Theory in pragmatics to instruct English majors to improve their listening comprehension ability, and tries to find an efficient teaching strategy of conversational implicature. The two classes are used as the experimental class and the control class respectively in this experiment. The experimental class adopts Conversational Implicature Teaching Strategy, while the control class still adopts the traditional teaching mode. The results show that the ability of conversational implicature inference of the experimental class is obviously better than that of the control class, which can effectively improve the listening comprehension level of the students. The results of the study provide some enlightenment for the implementation of conversational implicature teaching strategies in similar environments, and some suggestions for listening teaching of English majors are put forward based on the results of the study.
\end{abstract}

Index Terms - conversational implicature instruction, pragmatic-analysis, effectiveness, listening teaching, listening comprehension ability

\section{INTRODUCTION}

According to Grice's Conversational Implicature, in order to achieve specific communicative goals, both parties in discourse communication should abide by the Cooperative Principle (He, 2000). The cooperation principle is specifically embodied in four criteria: the maxim of Quantity, the maxim of Quality, the maxim of Relation and the maxim of mode Manner (Grice, 1975). However, in actual discourse communication, both sides of the communication do not strictly abide by these maxims, and sometimes the speaker deliberately or openly violates these maxims. At this time, the meaning of the discourse is not just the literal meaning. The listener should infer the purpose and implied meaning of the speaker's violation of the cooperative principle according to the context at that time. This implied meaning is called "Conversational Implicature" by Grice. Grice's theory of Conversational Implicature has become an important theory in pragmatics. Many researchers at home and abroad question this principle, either reinterpret it, or make amendments or supplements (Grice, 1984; Leech, 1983; Levinson,1987; Xu,1993; He,1997). However, many scholars have applied Conversational Implicature Theory to language teaching to explore its effectiveness in improving learners' English ability ( Bouton, 1990; Bouton, 1994; Harris \& Chen, 1994).

In the traditional listening teaching of ESP, teachers and students pay more attention to the surface structure of language, and listening comprehension still stays at the level of words and phrases. However, the research on listening teaching focuses more on the topics of listening skills and strategy training, and does not pay enough attention to the context issue, ignoring the cultivation of students' pragmatic awareness and ability. Therefore, researchers begin to apply Conversational Implicature Theory to English listening teaching. Buckhoff's research shows that the ostensive teaching of Conversational Implicature Theory can effectively improve the TOEFL listening scores of non-native English speakers (Buckhoff, 2011). Chinese scholars have also carried out researches on the relationship between Conversational Implicature Theory and English Listening Teaching (Liu, 2006). But, most of them still remain in the theoretical discussion level, and few people use objective experiments to test the effectiveness of a new teaching strategy, namely Conversational Implicature Teaching Strategy, in improving the listening comprehension ability of English majors. Therefore, through empirical research, this paper explores the effectiveness of applying Conversational Implicature Theory in pragmatics to instruct English majors to improve their listening comprehension ability, and attempts to demonstrate that Conversational Implicature Teaching Strategy is operable and effective.

\section{RESEARCH DESIGN}




\section{A. Research Purpose and Hypothesis}

This paper will study the application of Conversational Implicature Theory in listening teaching for English majors. The purpose of the research is to study the practicability of Conversational Implicature Theory in listening teaching for English majors. Guided by the Cooperative Principle and Conversational Implicature Theory, the teaching research is devoted to improving English listening teaching strategies, designing Conversational Implicature Teaching Strategies, cultivating students' ability to infer conversational implicature, so as to improve students' listening comprehension.

The research is designed and completed on the basis of a hypothesis. Hypothesis: using Grice's Conversational Implicature Theory to design Conversational Implicature Teaching Strategies to instruct English Major students' listening teaching has a positive impact and can improve students' English listening comprehension level, which is feasible and effective.

\section{B. Research Objects}

This experiment was conducted in the listening course of English majors in the School of Language and Culture of Shanghai University of Political Science and Law. The subjects of the experiment are sophomores majoring in English, a total of 102 students in 4 classes. The two classes are used as the experimental class and the control class respectively. The experimental class adopts Conversational Implicature Teaching Strategy, while the control class still adopts the traditional teaching mode. Among them, the teaching of English listening in experimental classes should introduce some pragmatic knowledge, such as Conversational Implicature Theory, to expand students' cultural background knowledge and improve their ability of thinking analysis and pragmatic reasoning. However, the teaching of English listening in the control class is still carried out in accordance with the traditional teaching mode, mainly explaining semantics knowledge such as vocabulary and grammar. The experiment adopts the test form, which is a combination of quantitative and qualitative. The experiment lasted for 15 Teaching weeks in a semester, with two English listening classes per class every week.

\section{Research Tools}

The research adopts the experimental form, which is a combination of quantitative and qualitative. The main tool of the experiment is the two test papers done before and after the semester. The purpose of the pre-test is to test the students' English listening comprehension level before the experiment, and the purpose of the post-test is to verify the effectiveness of Conversational Implicature Theory in the listening teaching of English majors. The results of tests taken before and after the semester are analyzed. Each test paper contains 20 short dialogues, each with a test question, each question is 5 points, the full score is 100 points.

\section{Research Steps}

The experiment started in September 2020 and ended in January 2021. There was one listening class every week, 90 minutes per class, for a total of 15 teaching weeks. The subjects of the experiment are all sophomores majoring in English from the school of language and culture, Shanghai University of political science and law.

This experiment was conducted in the listening course of English Majors in the school of language and culture, Shanghai University of political science and law. The subjects of the experiment were 102 students from 4 classes, majoring in English in School of Language and Culture of Shanghai University of Political Science and Law. The two classes are used as the experimental class and the control class respectively.

The teaching material used in the experiment is A Listening Course 2 (Third Edition) (Shanghai Foreign Language Education Press), in which the Listening materials are mostly drawn from life, vivid and close to reality. During the experiment, the experimental class and the control class used the same teaching materials and different teaching methods to verify the experimental hypothesis. In the control class, the traditional teaching mode is adopted, and the content of pragmatics such as conversational meaning theory is not involved. In the classroom, each class first spends 20 minutes to learn about semantics such as vocabulary, phonetics, grammar, etc. according to the traditional model, and then 40 minutes to do listening exercises and check the answers. In the last 30 minutes, explain the exercises, and mainly supplement the vocabularies, phrases, and grammars and other semantic knowledge in the exercises.

In the experimental class, pragmatic knowledge such as Conversational Implicature Theory is introduced to guide listening teaching, and cultural background knowledge, pronunciation and intonation, context and other related knowledge are appropriately introduced to consolidate and improve students' listening level through training.

The experiment can be divided into two stages: the first stage is the theoretical explanation stage (the first six weeks). In this stage, the teacher gradually explains the cooperative principle and Conversational Implicature Theory to the students, supplemented by exercises to consolidate. The second stage is the practice intensive stage (the last 9 weeks). In this stage, students have basically mastered conversational implicature and its related theoretical knowledge, so the classroom teaching in this stage is mainly to consolidate and strengthen the knowledge learned through a large number exercises and explanations, so as to achieve the ultimate goal of improving students' listening level.

Next, we will describe the whole process of listening strategy training in detail according to the two stages of the experiment.

\section{Theoretical Explanation Stage}


The first stage is the theoretical explanation stage, which lasts for 6 weeks. In this stage, teachers spend 20 minutes to explain the theory in each class, and give a lot of examples to facilitate students' understanding. Then do the listening exercises for 40 minutes and check the answers. In the last 30 minutes, explain the exercises and focus on the types of questions related to conversational implicature. As mentioned in this paper, the main content of the theoretical explanation is cooperative principles and maxims, as well as the related theory of violating the maxims.

Dialogue is the main type of listening materials in ESP listening textbooks. Moreover, most of the content in the textbooks for English majors is drawn from daily life, vivid and close to reality. The theory of conversational implicature is just about the understanding of conversational implicature. Therefore, we try to use Conversational Implicature Theory to guide English listening teaching and explain listening materials in order to improve students' listening comprehension level.

\section{Example 1:}

M: How did you like the movie yesterday?

W: I should have gone swimming with you instead.

Q: What does the woman mean?

In this dialogue, $\mathrm{M}$ asked $\mathrm{W}$ what did she think of yesterday's movie, and $\mathrm{W}$ replied that she should really go swimming with W. Obviously W violated the maxim of relevance and said something irrelevant to the topic. However, assuming that W is willing to cooperate, we can infer that W's implication is: Yesterday's movie was really bad.

So, let's take a look at the options for this question:

A: She didn't like the movie.

B: She went swimming instead.

$\mathrm{C}$ : She enjoyed the movie very much.

According to the above analysis, the answer is obviously A.

\section{Example 2:}

Man: Well, what do you think of the movie?

Woman: I don't know why I let you talk me into going. I just don't like violence. Next time you'd better choose a comedy.

Question: What can we infer from the conversation?

A) The woman hated the man talking throughout the movie.

B) The woman saw a comedy instead of a horror movie.

C) The woman prefers light movies before sleep.

D) The woman regrets going to the movie .

In this dialogue, when the man asked the woman what she thought of the movie, the woman did not make a direct comment, but said, "I don't know why you will be convinced to go to the movie. I don't like violence. Next time you'd better choose a comedy." This obviously violates the "brevity" and "avoidance of obscurity" in the way maxims. But it was the lady's endless chatter that aptly expressed her deep regret at this time and regretted going to the movie, so the answer was D.

\section{Practice Strengthening Stage}

The second stage is the practice intensive stage, which lasts for 9 weeks. In the first stage, students initially learn and understand the relevant theories of conversational implicature, but this understanding is often preliminary, superficial and isolated, and has not yet been transformed into a part of students' knowledge system. Therefore, students must truly comprehend and internalize what they have learned in practice through a great deal of practice.

At this stage, students in each class first use 50 minutes to do exercises, and then the teacher uses 40 minutes to explain the exercises in a targeted manner, and appropriately supplement cultural background knowledge, pronunciation and intonation, vocabulary, grammar and other related knowledge. At the same time, it is suggested that students expand their vocabulary and develop their sense of language by reading English original works, reading English newspapers, magazines, novels, watching original movies, listening to English programs on radio and television, etc. At the same time, they can also understand the differences between Chinese and Western cultures and reserve more cultural background knowledge.

\section{Example 3}

W: Shall we talk about Mr. Johnson?

M: Well, he is a senior citizen at first.

Q: What does she mean?

The key to understanding this dialogue is to grasp the word "senior citizen". At aboard, people are unwilling to admit that they are getting old or have grown old. Therefore, for the sake of politeness, people rarely ask about their age when talking, and when describing others, the word "old" should be avoided as much as possible. Therefore, in this dialogue, W asked $\mathrm{M}$ if he could introduce Mr. Johnson to her. M only used "senior citizen" instead of "old people". If students understand the differences between Eastern and Western cultures, it is not difficult to make correct judgments.

\section{ReseARCh RESUlts AND ANALysis}




\section{Comparison and Analysis of Pre-test and Post-test Results}

\section{A. Comparison and Analysis of the Pre-Test Results of the Experimental Class and the Control Class}

Before the beginning of this semester, a test (pre-test) was conducted on the students in the experimental class and the control class. The purpose of the pre-test experiment is to master the students' listening comprehension level and listening comprehension ability before the experiment. The test consists of 20 short dialogues, each with one question, 5 points for each, 100 points in total.

The following are the pre-test scores of the experimental class and the control class:

TABLE 1

PRE-TEST SCORES OF THE EXPERIMENTAL CLASS

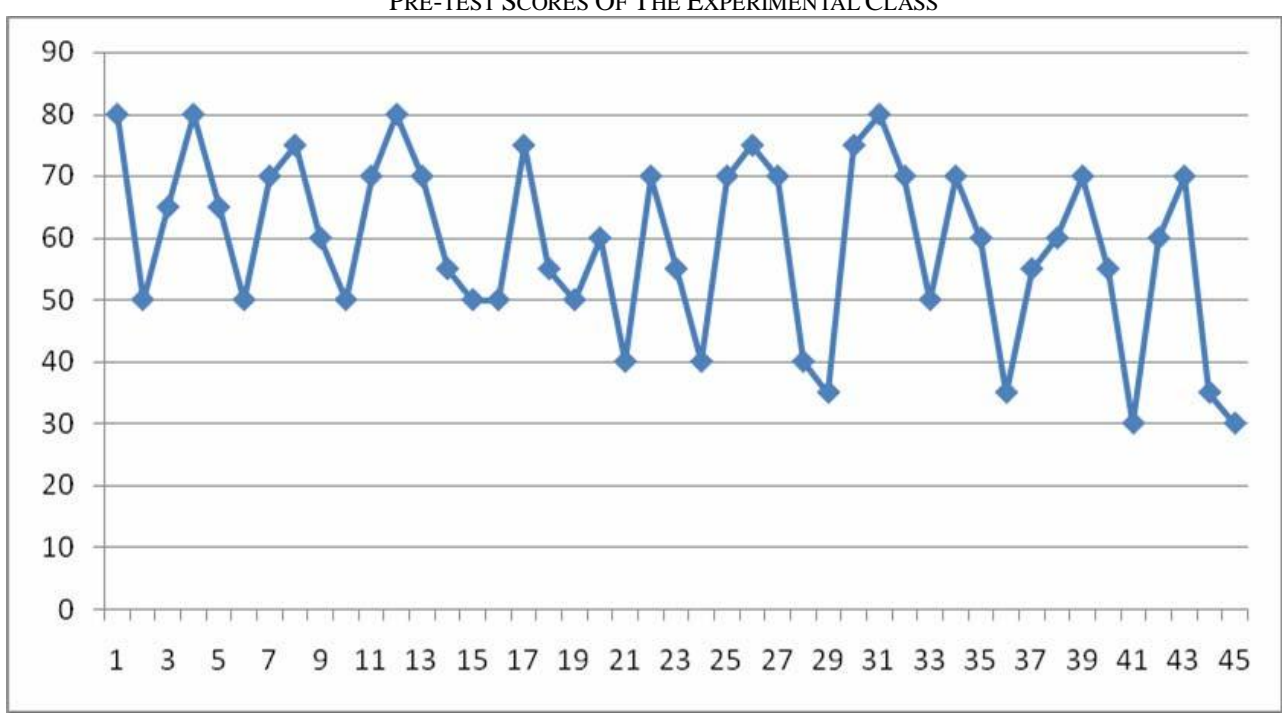

TABLE 2

PRE-TEST SCORES OF THE CONTROL Class

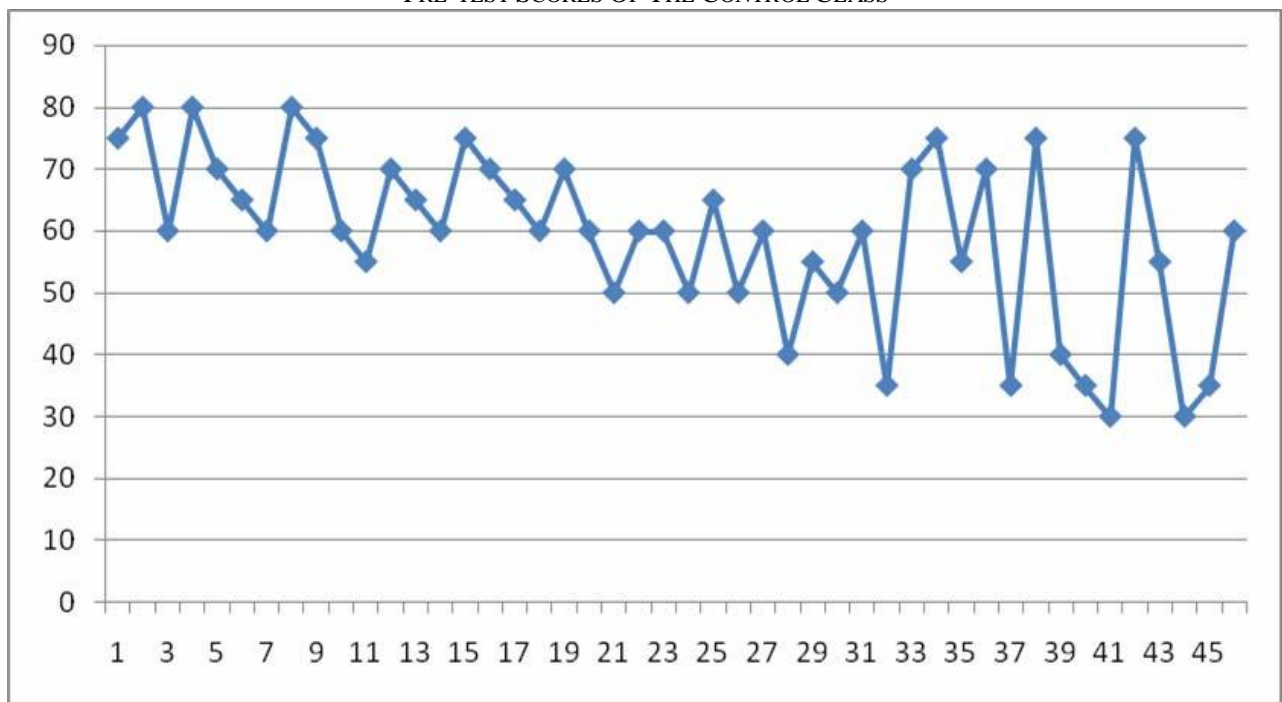

According to the pre-test scores of the experimental class and the control class, this paper uses SPSS 17.0 system to compare and analyze the scores of the experimental class and the control class, and Table 3 and Table 4 are obtained:

TABLE 3

Data STATISTICS OF PRE-Test Results OF EXPERIMENTAL Class AND CONTROL Class Group statistics

\begin{tabular}{|l|l|l|l|l|l|}
\hline & class & $\mathrm{N}$ & mean value & standard deviation & $\begin{array}{l}\text { Standard error of } \\
\text { mean }\end{array}$ \\
\hline Scores & 1 & 43 & 58.1068 & 13.45130 & 2.14000 \\
& 2 & 44 & 58.0478 & 13.00820 & 2.06541 \\
\hline
\end{tabular}

Table 3 is the comparison of statistical data of pre-test results between the experimental class and the control class. Before the experiment, the average score of the experimental class was 58.10, while that of the control class was 58.04. The difference between the two classes was very small. It can be inferred that the English listening level of the 
experimental class and the control class is roughly the same before the experiment. In other words, the students in the two classes are basically at the same listening level. In addition, the overall listening level of students in the two classes is not high.

TABLE 4

INDEPENDENT SAMPLE TeSt OF PRE-Test Results Of EXPERIMENTAL Class AND CONTROL Class Independent sample test

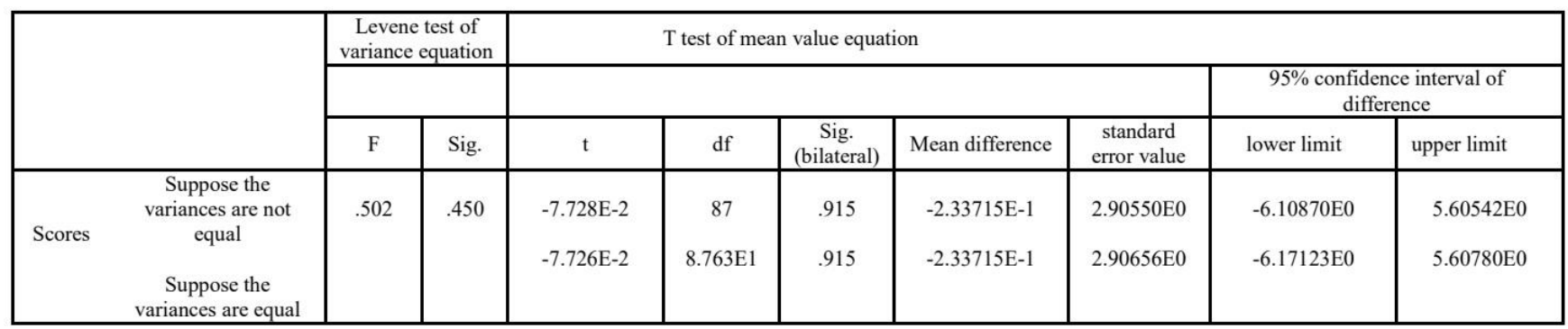

Table 4 is the independent sample test of the pre-test results of the experimental class and the control class. Among them, $\mathrm{P}($ Pearson $)=0.907>0.05$, indicating that there is no significant difference between the experimental class and the control class through the comparison of their performance. In other words, before the paper experiment, the students in the experimental class and the control class were roughly at the same listening level. This is also the premise and basis of the experiment.

\section{B. Comparison and Analysis of Post-Test Results between the Experimental Class and the Control Class}

At the end of this semester, the experimental class and the control class are tested again (post test). The purpose of the post-test is to detect whether the English listening level of the experimental class and the control class is different before this semester, and to detect whether the improvement of English Listening Teaching Mode under the guidance of Conversational Implicature Theory can improve the students' English listening level. The test consists of 20 short conversations with a topic under each conversation, and each question is marked 5 points for a total of 100 points.

The post-test scores of the experimental class and the control class are as follows:

TABLE 5

POST-TEST SCORES OF THE EXPERIMENTAL CLASS

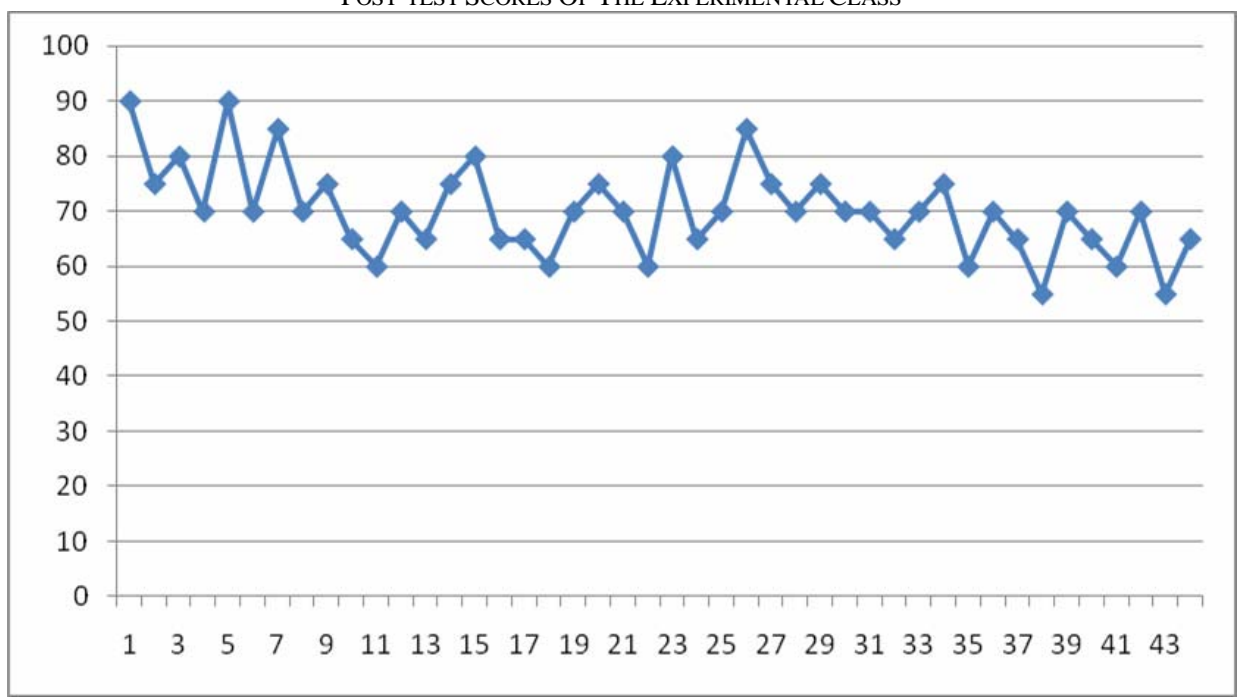


TABLE 6

POST-TEST SCORES OF THE CONTROL CLASS

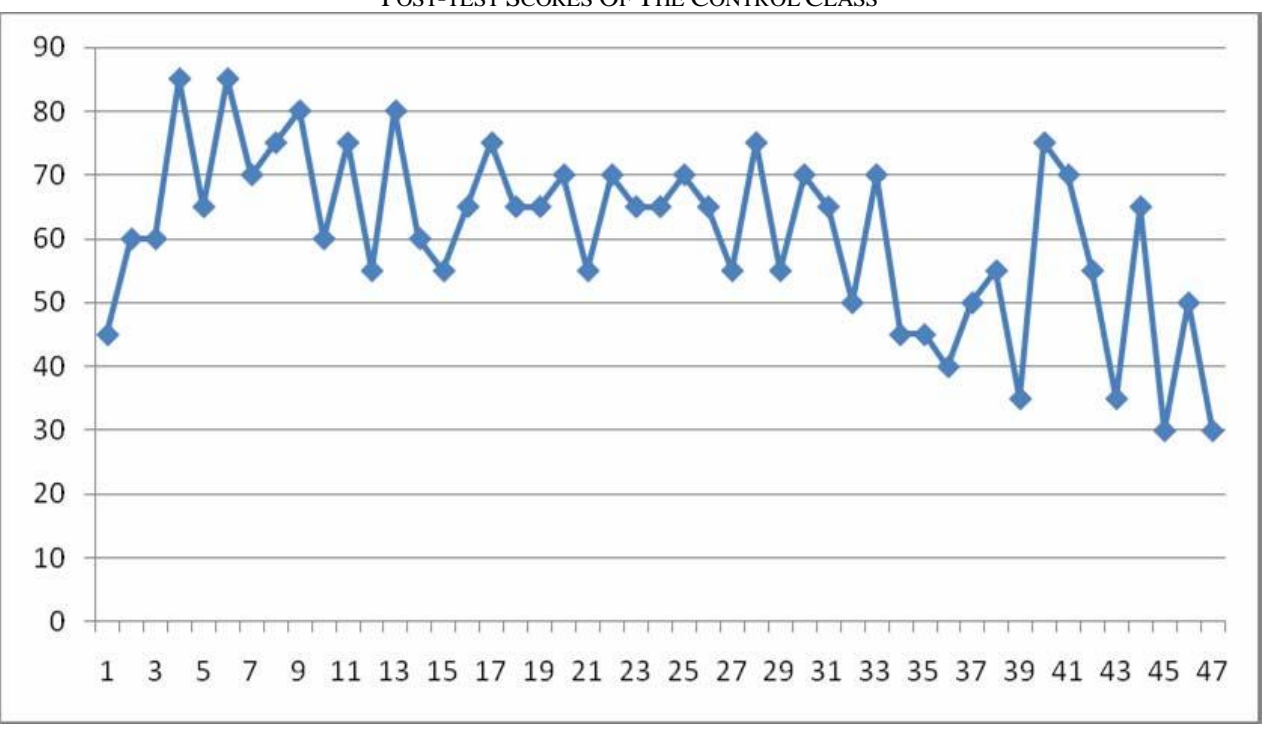

According to the post-test scores of the experimental class and the control class, SPSS 17.00 system is used to compare and analyze the scores of the experimental class and the control class, and Table 7 and Table 8 are obtained:

TABLE 7

DATA STATISTICS OF POST-TEST RESUlts OF EXPERIMENTAl Class AND CONTROL Class Group statistics

\begin{tabular}{|c|c|c|c|c|c|}
\hline & class & $\mathrm{N}$ & mean value & standard deviation & $\begin{array}{c}\text { Standard error of } \\
\text { mean }\end{array}$ \\
\hline Scores & 1 & 45 & 68.5667 & 8.94427 & 1.33333 \\
& 2 & 46 & 60.1957 & 13.67011 & 2.01555 \\
\hline
\end{tabular}

Table 7 is a comparison of statistical data of post-test results between the experimental class and the control class. After the experiment, the average score of the experimental class in the pre-test was 68.57, and that of the control class in the post-test was 60.20. The average score of the two classes was very different. The average score of the experimental class was significantly higher than that of the control class $(68.57>60.20)$.

In addition, if Table 3 is compared with table 7, that is, the pre-test and post test scores of the experimental class and the control class, we can find that: (1) the average score of the pre-test in the experimental class is 58.10 , the average score of the post test is 68.57, and the post test scores are significantly improved than the pre-test. (2) The pre-test score of the control class was 58.04, and the post-test score was 60.20 . The post-test score was slightly higher than the pre-test score, but the increase was not obvious. (3) In the pre-test, the scores of the experimental class and the control class were roughly the same, and the students of the two classes were at the same level in listening. In the post-test, the performance of the experimental class was significantly higher than that of the control class. The two classes were no longer at the same level, and the experimental class was significantly better than the control class.

TABLE 8

INDEPENDENT SAMPLE TEST ON POST-TEST RESUlts OF EXPERIMENTAL Class AND CONTROL Class Independent sample test

\begin{tabular}{|c|c|c|c|c|c|c|c|c|c|c|}
\hline & & \multicolumn{2}{|c|}{$\begin{array}{c}\text { Levene test of variance } \\
\text { equation }\end{array}$} & \multicolumn{7}{|c|}{$\mathrm{T}$ test of mean value equation } \\
\hline & & \multirow[b]{2}{*}{$\mathrm{F}$} & \multirow[b]{2}{*}{ Sig. } & \multirow[b]{2}{*}{$\mathrm{t}$} & \multirow[b]{2}{*}{$\mathrm{df}$} & \multirow[b]{2}{*}{$\begin{array}{c}\text { Sig. } \\
\text { (bilateral) }\end{array}$} & \multirow[b]{2}{*}{$\begin{array}{c}\text { Mean } \\
\text { difference }\end{array}$} & \multirow[b]{2}{*}{$\begin{array}{l}\text { standard } \\
\text { error value }\end{array}$} & \multicolumn{2}{|c|}{$\begin{array}{c}95 \% \text { confidence interval of } \\
\text { difference }\end{array}$} \\
\hline & & & & & & & & & lower limit & upper limit \\
\hline Scores & $\begin{array}{c}\text { Suppose the } \\
\text { variances are not } \\
\text { equal } \\
\text { Suppose the } \\
\text { variances are equal }\end{array}$ & $8.681 \mathrm{E} 0$ & $\begin{array}{c}.004 \\
3.505 \mathrm{E} 0\end{array}$ & & $\begin{array}{r}89 \\
7.77 \\
7 \mathrm{E} 1\end{array}$ & $\begin{array}{l}.001 \\
.001\end{array}$ & $\begin{array}{l}8.47101 \mathrm{E} 0 \\
8.47101 \mathrm{E} 0\end{array}$ & $\begin{array}{l}2.42743 \mathrm{E} 0 \\
2.41665 \mathrm{E} 0\end{array}$ & $\begin{array}{l}3.64776 \mathrm{E} 0 \\
3.65960 \mathrm{E} 0\end{array}$ & $\begin{array}{l}1.32943 \mathrm{E} 1 \\
1.32824 \mathrm{E} 1\end{array}$ \\
\hline
\end{tabular}

Table 8 is an independent sample testing of the post-test results of the experimental class and the control class. Among them, $\mathrm{P}=0.001<0.05$, indicating that there is a significant difference between the experimental class and the control class through the comparison of their scores. In other words, after our experiment, the students in the experimental class and the control class have obvious differences in their scores, and the scores of the experimental class are significantly better than that of the control class. 
In addition, if Table 4 is compared with Table 8 , that is, the independent sample test results of the pre-test and post-test scores of the experimental class and the control class are compared, we can find that: (1) In the pre-test independent sample test of the experimental class and the control class, $\mathrm{P}=0.907>0.05$, indicating that before the paper experiment, students in the experimental class and the control class were at roughly the same listening level. (2) In the independent sample test of the post-test results of the experimental class and the control class, $\mathrm{P}=0.001<0.05$, indicating that after the experiment, there is a significant difference in the English listening performance of students from the experimental class and the control class, and the performance of students from the experimental class is significantly higher than that of the control class.

Therefore, the experiment shows that the students in the experimental class are better than those in the control class in inferring conversational implicature in listening comprehension, which can effectively improve the listening comprehension level of students. The results show that Conversational Implicature Teaching Strategy is effective and feasible for English majors to improve their listening comprehension ability. Moreover, it is of practical significance to explore and apply Conversational Implicature Theory in pragmatics to guide the listening teaching of English majors. However, it should be noted that the differences in listening comprehension ability in this study only existed among English majors in the School of Political Science and Law. The results of this study provide some enlightenment for the implementation of Conversational Implicature Teaching Strategy in similar environments. In Section IV of this paper, some suggestions for listening teaching of English majors are proposed based on the results of this study.

\section{TEACHING ENLIGHTENMENT}

The research shows that the application of Conversational Implicature Theory to ESP listening teaching is helpful to improve students' conversational implicature comprehension ability in listening, and then improve their listening level. Therefore, the combination of students' English listening ability training and pragmatic ability training, through targeted training, is helpful to cultivate students' ability to use relevant pragmatic strategies to analyze and infer the material they hear, and ultimately improve students' English listening comprehension ability. Based on the results of the experimental teaching, this paper puts forward some suggestions on the teaching of ESP listening.

\section{A. Pay Attention to the Teaching of Pragmatic Knowledge}

He Ziran (1997) once said that English learning is the process of cultivating students' pragmatic competence. The teaching of English listening for English majors should be no exception. In listening teaching, we should also pay attention to cultivating students' pragmatic ability.

Listening comprehension is far more than just understanding the literal meaning of words and sentences, it includes understanding the conveyance meaning of the speaker (Brown \&Yule, 1983). In the process of listening comprehension, although it is possible for students to hear every word clearly, they cannot accurately understand the conveyance meaning of the whole sentence. Pragmatic knowledge can help students to carry out effective pragmatic reasoning, so that students can understand the implied meaning of the discourse through the surface language form. The research shows that the development of pragmatic competence does not develop naturally with the development of linguistic competence. In listening teaching of English majors, it is necessary to carry out targeted teaching of pragmatic competence (Hong, 1991). The listening textbook does not provide any relevant pragmatic knowledge, so it is necessary for teachers to convey some relevant pragmatic knowledge to students in normal teaching.

In this way, students can make effective pragmatic inferences based on the pragmatic knowledge they have learned during the listening process, understand the implied meaning of the utterance, and improve their listening comprehension ability.

This study, based on Conversational Implicature Theory, shows that Conversational Implicature Teaching Strategy is effective in English listening teaching for English majors and can improve students' listening comprehension ability. In listening teaching, in addition to Conversational Implicature Theory involved in this study, teachers can also make students understand cultural background knowledge and enhance students' awareness of cultural context. Teachers should guide students to understand the cultural background of foreign countries and the cultural differences between China and the aboard as much as possible so as to guide students to better grasp the implied meaning expressed in the discourse.

\section{For example, 4}

M: Have you seen Tom these days?

W: Of course, for many times. He always drops by just at lunch. And I would be happier if he could call ahead.

Q: Why does the woman mean?

This dialogue involves the differences between Eastern and Western cultures in daily etiquette and behavior habits. In daily life, Chinese people often visit home to express friendship and enthusiasm, but it is not polite to visit others when they are eating; in the West, it is necessary to make an appointment with others before visiting, otherwise it will disrupt other people's plans and arrangements and cause the interviewees to be unhappy. Therefore, according to the context of the dialogue and the corresponding cultural background knowledge, the reason why the speaker in the dialogue is dissatisfied with Lucy should be that he did not call to make an appointment before the visit.

So, let's look at the choices in this question: 
A: She is very happy because Tom frequently drops these days.

B: She frequently calls Tom.

C: She is not very happy because Tom doesn't phone ahead before visiting.

Based on the above analysis, the answer is obviously C. However, many students chose the wrong option A. These students obviously do not know enough about the cultural background of the East and the West. Therefore, it is absolutely necessary for teachers to properly introduce relevant knowledge of cultural background in the class.

In order to improve students' pragmatic inference ability and cultivate students' pragmatic competence, teachers should also integrate the application of relevant pragmatic strategies in their listening teaching. When analyzing and explaining listening training materials, teachers should not simply tell students the answers or explain the surface structure of listening materials, but should explain and analyze the deep or implied meaning of utterances, so as to naturally arouse students' pragmatic awareness and cultivate their pragmatic competence in the process of listening teaching.

\section{B. Carefully Select and Design Listening Materials}

In this experiment, some long and short dialogues with conversational implicature are used as teaching cases to analyze and explain the conversational implicature, so as to help students improve their listening comprehension ability of conversational implicature. The results show that it is effective. Therefore, in ordinary listening teaching, teachers should try their best to select authentic listening materials and present different language communication environments, which can not only stimulate students' interest, but also enable students to understand the characteristics of language use in different contexts and cultivate students' pragmatic awareness and competence.

The listening materials can be diversified, which can be daily conversations, speeches, interviews, news broadcasts and even songs, as well as audio or video (such as movie clips, etc.). These materials can be selected from English radio or television programs, so that they are more authentic in terms of content, context, or language itself. Real, natural and diversified listening materials can give students a better exposure to a rich variety of languages and their use in different life scenarios.

It should be particularly pointed out that English listening textbooks or teachers' books should provide specific teaching and learning materials for listening course teaching. However, the existing listening textbooks rarely involve the content design of the interpretation and annotation of pragmatic knowledge. Therefore, in order to make reasonable and effective use of English listening teaching materials, teaching materials play a role in course teaching. We suggest that the following suggestions should be considered when designing textbooks: (1) Provide as many listening materials as possible that reflect real communication, and introduce some pragmatic knowledge contained in them; (2) annotate the pragmatic knowledge embodied in the dialogues and short passages in the textbook; (3) Present the pragmatic knowledge points in teachers' books or annotate the pragmatic knowledge that appears in the textbook, and so on. In this way, teachers can explain the pragmatic knowledge in the listening materials with the help of textbooks or teachers' books, so as to better cultivate students' pragmatic awareness.

This study shows that the application of Conversational Implicature Theory to ESP listening teaching can improve students' conversational implicature comprehension ability, and thus promote their listening comprehension ability. This study only applies Conversational Implicature Theory to ESP listening teaching, and more pragmatic theories can be incorporated in the future research. In a word, the cultivation of listening ability is a long-term accumulation process. How to effectively cultivate students' listening ability needs further study.

\section{REFERENCES}

[1] Bouton, L. F (1990). The effective use of implicature in English: Why and how it should be taught in the ESL Classroom //Bouton L F. Kachru Y. Pragmatics and Language Learning. Illinois: Division of English as an International Language, University of Illinois at Urbana-Chmpaign, (1): 43-52.

[2] Bouton, L. F (1994). Conversational implicature in a second language: Learned slowly when not deliberately taught. Journal of Pragmatics, (22):157-167.

[3] Brown, G.\&Yule. G. (1983). Teaching the Spoken English. Cambridge: Cambridge University Press.

[4] Buckhoff, M. (2011) Teaching Students Implied Meaning for TOEFL Preparation Listening [EB/OL]. (09), 12. http://buckhoff. topcities.com/ UCRpresentation.htm [retrieval time: 2021-03-12].

[5] Grice H P. (1975). Logic and conversation. // Cole P, Morgan J. Syntax and Semantics, Vol.3: Speech Acts. New York: Academic Press, 41-58.

[6] Harris, J. \& Chen, R. (1994) Understanding Implicature and the ESL Program. Illinois: University of Illinois at Urbana-Champaign.

[7] He Zhaoxiong, Yu Dongming, Hong Gang,et al. (2000). A new outline of pragmatics. Shanghai: Shanghai Foreign Language Education Press.

[8] He Ziran. (1997). Pragmatics and English learning. Shanghai: Shanghai Foreign Language Education Press.

[9] Hong Gang. (1991). A survey of English pragmatic competence and its implications for foreign language teaching. Foreign language teaching and research, (4):56-60.

[10] Horn, L. R. (1984). Toward a new taxonomy for pragmatic inference: Q-based and R-based implicature//Schiffrin, D. Meaning, Form and Use in Context: Linguistic Applications. Washington D C: Georgetown University Press, 11-42.

[11] Leech, G. (1983). Principles of Pragmatics. London: Longman. 
[12] Levinson, S.C. (1987). Pragmatics and the grammar of anaphora: A partial pragmatic reduction of binding and control phenomena. Journal of Linguistics, (23) :379-434.

[13] Liu Shijuan, Sun Bian Qi. (2006). Conversational meaning in English listening. Journal of Shanxi Normal University: Social Science Edition (6):135-137.

[14] Xu Shenghuan. (1993). New development of conversational implicature theory. Modern foreign languages, (2):7-15.

Shifang Li was born in Shangzhi, China in 1967. She received her PH. D degree in English Language and Literature from Northeast Normal University, China in 2008.

She is currently a professor in the School of Languages and Cultures, Shanghai University of Political Science and Law, Shanghai, China. Her research interests include Forensic Linguistics, text analysis and Pragmatics Linguistics.

Dr. Li is an executive director, deputy secretary general, of the Legal Linguistics Committee of China. 